Оригинални научни рад

УДК 347.77/.78(439)“18“

doi:10.5937/zrpfns46-1968

Tamás Nótári, Associate Professor

Károli Gáspár University, Budapest

\title{
PROTECTION OF INTELLECTUAL PROPERTY IN HUNGARIAN JURISPRUDENCE OF THE $19^{\mathrm{TH}}$ CENTURY
}

\begin{abstract}
Given the peculiarities of historical development, modern codification efforts evolved with a delay in the Age of Reforms in the eighteen-thirties; with respect to copyright the Bills related to Bertalan Szemere are worth mentioning. After suppression of the War of Independence (1849) and the Compromise (1867), basically Austrian laws were applied. The history of Hungarian copyright law is characterised both by successful and unsuccessful attempts at codification, although aborted bills failed due to changes in historical circumstances rather than the standard of proposals. The Bill submitted by Bertalan Szemere to the National Assembly in 1844 was not enacted for lack of royal sanctioning. Following the age of imperial patents and decrees, after the Compromise (1867) the Society of Hungarian Writers and Artists put forth-again an unsuccessfulmotion for regulation; however, the Commercial Code, Act XXXVII of 1875 devoted a separate chapter to regulation of publishing transactions. The first Hungarian copyright law, Act XVI of 1884, was made following László Arany's initiative, upon István Apáthy's motion. The Act implemented modern codification adjusted to bourgeois conditions, setting out from theoretical bases of intellectual property not superseded ever since. In this paper first, we will the suggestions of Ferenc Toldy on protection of intellectual property, then we will examine the early stages of statutory protection of author's works in Hungary, and finally, we will analyse the discuss Bertalan Szemere's role in regulation of copyright and his 1844 Copyright Bill. ${ }^{1}$
\end{abstract}

Key words: intellectual property, Hungarian law of copyright, Ferenc Toldy, Bertalan Szemere

${ }^{1}$ On further aspects of Hungarian copyright law see Nótári T.: A magyar szerzői jog fejlödése [Development of Hungarian Copyrght Law]. Szeged 2010. 


\section{Ferenc Toldy's proposals on protection of copyright}

In the Age of Reforms members of Hungarian society met with several fields that had not been legally regulated until then. That is how placement of intellectual works in the legal system must have arisen as a fundamental problem because until the beginning of the Age of Reforms the "profession" of writers had not developed, there had been no periodicals, newspapers, and dramatic art and play-writing could not develop as an independent genre.

Two articles of Ferenc Toldy calls the attention to filling this gap in the law and reveal extraordinary expertise and rhetorical competence. His first article written on the topic was published in the columns of Athenaeum in 1838 entitled "A few words on writer's property and petition to publishers of periodicals", 2 the other one in the Budapesti Szemle in 1840 under the title "On writer's property". 3

First, he defines the concept of property clearly as follows: "Everything that we acquire by either our own internal talents or external tools without harm to alien rights is our unalienable true property, mortmain." The definition contains every important element concerning the criteria of property. After that he translates the term of property to intellectual works and proves that once having obtained a form through printing it becomes property and unalienable property at that. ${ }^{4}$ Furthermore he defines the term of reprint/impression/: "misappropriation committed on true property". 5

Once he has clarified fundamental terms, he expounds them in details: first of all, everybody can freely dispose over his property (ius disponendi). He can do it in the following forms according to Toldy: "He may transfer his original right to other persons at his discretion, ... he may disclaim the property ... until he does not do that clearly or, knowing that, does not abandon it or does not let it lapse, nobody shall encroach upon his rights to this natural property". 6 Toldy expounds the process how a writer's thought becomes a thing. If he disposes of it by gift or sale, he always does it conditionally. He does not sell the work of intellect; instead, he lets some unique thing, copy, instrument on moral lease. By his work the author conveys ideas, information to the buyer, and the buyer processes them and integrates them in his store of knowledge. "The author has not attached, cleverly could not have attached, has not put up for sale any other

${ }^{2}$ Toldy (Schedel) F.: Néhány szó az irói tulajdonról [A few words on writer's property]. Athenaeum, 1. 1838. 705-717.

${ }^{3}$ Toldy (Schedel) F.: Az írói tulajdonról [On writer's property]. Budapesti Szemle, 1. 1840. 157-237.

${ }^{4}$ Toldy 1838.705 .

5 Toldy 1838706 .

${ }^{6}$ Toldy 1838. 706 . 
right to any copy of his work on sale: the buyer has not bought, could not have bought anything else so he does not have anything more than such intellectual utilisation". "This is a consensual contract that-in the absence of any stipulations to the contrary-cannot be attacked or doubted either morally or legally.

Toldy's reasons contain statements valid even today. Regulation of writer's property in an act is an indispensable task of the State because the writer and his intellectual work is public domain, which shapes the edification, intellectual and ethical moral of society. Society's task is to appreciate the writer and to ensure that the writer could spend all his time and power on creation, development of his own intellect: thereby he will produce works that serve the edification, progress of the whole country. If a writer does not see the reward of his talent and efforts or not even recovery of his financial expenses certified, he will leave this career, which makes society, science poorer. In his opinion it is a fundamental condition that each state should protect its own intellectual products and based on reciprocity should not authorise reprinting or sale of foreign literary works. (Several countries authorised or did not forbid reprinting of foreign works or sale of reprints: ${ }^{8}$ France, Belgium, the United States of America, the states of the Deutscher Bund and Austria too-the latter was a hotbed of unrestricted reprinting both of foreign and the greatest German literary works: these printing houses were protected by the state too.) Toldy asserts that the really blissful situation would be if states did not authorise reprinting and they purchased original works from each other, and the rate of imports/exports would depend merely on "which country provides its citizens with more instruments, support, which is indispensable and necessary in the world of science".

Toldy claims that only one reason can be raised as an excuse, which somewhat explains advocacy for reprints: "and that is expensiveness of original editions". ${ }^{10}$ As a matter of fact, he does not accept this reason either, as he knows that these books are more expensive because publishers can cover their costs from sold copies only. In his opinion publishers could sell their books cheaper if they should not be afraid of reprinters, since more copies could be printed and sold with greater safety: the less a reprint costs and the more certain buyers win, the more lawful owners, publishers and writers lose. The writer because the publisher cannot pay for his efforts according to his merits and the publisher because its profit from the enterprise is dubious. Yet, it is not only the individual but also the state that incurs loss because thereby in the long run

\footnotetext{
${ }^{7}$ Toldy $1840.160 . \S 4$.

${ }^{8}$ Toldy 1838.707 .

${ }^{9}$ Toldy 1838.708 .

${ }^{10}$ Toldy 1838. 709 .
} 
scientific life, scientific development will be endangered and society will lag behind in development. Writer's work cannot be distinguished from other breadwinner activities, so it should be paid for. However, the issue of paying a fee is a rather complicated task. Toldy raises several possibilities.

On the one hand, it would be possible that the state should give salary to writers. This would not be a path to be followed because it could not be financed from the country's budget and it is problematic also because a standard to measure writers should be determined and only those who comply with this measure would be given salary. To avoid this, a reward of equal rate could be set, which is not a suitable method because there are huge differences between writers: "And intellect cannot be measured by a man's arm."11 He raises the possibility that the state should make writer's property free "by giving the right to writers to claim dividend from publishers on each printed or already sold copy. ... But who will set this dividend? Who will check the number and sale of copies?",2 Questions, questions, questions, to which Toldy claims there is only one answer: when the state acknowledges writers' property right on their works, or to put it in other words, forbids reprinting. "The public-vox populi-will reward its writers this way."

The solution could be only to make law. He considers the German act promulgated on 9 November 1835 an example to be followed in this subject, which obliged each province of the German Federation individually and mutually to acknowledge and protect both scientific and artistic property at least for ten years against reprinters as well as prohibited sale of reprints brought in from abroad and threatened with penalty. Penalty determined by the laws of provinces were imposed on reprinters and sellers of reprints, each copy and the instruments used for preparatory works were confiscated from them, and they were obliged to give full redress and compensation to the writer and the publisher. The Prussian government made an even stricter law covering all aspects, to consist of thirty-eight sections, which now regulated the issue of reciprocity and "retaliation" concerning foreign states.

Until then the issue of writer's property had not been put on the agenda of legislation in Hungary "because there was no reason for worrying about it" and "if it has been injured, the injury has been overlooked or has not become subject of any complaint". ${ }^{14}$

Toldy, however, looks into the future with hope: he mentions Kazinczy's language reform efforts, publication of count István Széchenyi’s book entitled

\footnotetext{
${ }^{11}$ Toldy 1840. 161. $\S 5$.

12 Toldy $1840.162 . \S 5$.

${ }^{13}$ Toldy $1840.162 . \S 5$.

${ }^{14}$ Toldy 1838. 711.
} 
Credit, foundation of the Hungarian Academy of Sciences and thereby the foundation of a new layer in civil society: the layer of writers. Literature came to life because now it had permanent audience, especially through the work of the press, and this participation, no matter how low its rate was compared to the five million population, did not give cause for dissatisfaction. Editors of periodicals were considered pioneers such as Károly Kisfaludy who paid honorarium on larger studies published in the columns of Aurora edited by him. József Bajza was the first who paid for all the studies published in his almanac, and in a predetermined system at that. Thereby intellectual work began to become goods and the idea of ownership involved in goods became reality.

\section{Early stages of statutory protection of author's works in Hungary}

Regulation of copyright in Hungary was strongly linked to the Austrians. Its starting point was the exclamation by Ádám Takács addressed to lawmakers, in which the protestant minister from Göny called the attention of the Governor's Council to the fact that having defiled the work of printer Paczkó in Pest who published his funeral orations, printer Landerer reprinted the whole volume, ... due to the loss caused by it Paczkó withdrew from publishing the second volume being afraid of Landerer stealing it again. ${ }^{15}$ To prevent continuation of this foul play, the minister turned to the Governor's Council as a result of which on 3 November 1793 the royal decree number 12157 was issued, which was the revised version of the decree dated 11 February 1775 in Austria. It sanctioned inland reprint by penalty and confiscation as well as compensation to be paid to the author. All this, however, did not apply to books published abroad and already reprinted inland by others, they could be freely published by anybody. It extended legal protection to the writer's legal successor (cessionarius) and formulated the institution of limitation well-known from later periods, which stated that after a certain period elapsed after the author's death the work became public domain and could be published freely by anybody but it did not set its detailed rules yet. In 1794 by another royal decree (no. 1812) it added reciprocity to it: it was prohibited in Hungary to reprint works printed in Austria, and the same protection was provided for works published on Hungarian territories against Austrian reprints. This rule was in force until the above mentioned Hungarian-Austrian international agreement (Act IX of 1887) was entered into. ${ }^{16}$ Protection, however, proved to be underdeveloped because only the "preliminary path" formulating censorship existed instead of the judicial path. The scope of protected works was further widened by the court decree no.

\footnotetext{
${ }^{15}$ Kelemen 1869. 311; Balogh 1991. 151.

${ }^{16}$ Kenedi 1908. 9.
} 
4232 dated 22 April 1831, which extended protection to "drawings and copper engravings".

In the middle of the $19^{\text {th }}$ century, however, literary, scientific and political life in our country flourished, strongly helped by reproduction. Simultaneously with progress, claims were received on abuses of copyright. The first highly significant writings on the topic can be linked to Ferencz Toldy, as it has been described above already.

The Kisfaludy Society seemed to be a committed adherent of lawmaking for a long time. They made their first attempt in 1844 when the board worked out a draft. This bill was forwarded to Bertalan Szemere to make it more accurate, who made the final version heavily under the influence of the 1837 Prussian copyright act and the 1843 Hungarian criminal law concept. On the one hand, he extended the scope of protection (in addition to author's works, theatre plays, musical works, drawings and paintings were defined); on the other hand, he defined the term of protection as a period of fifty years different from the average because thereby both the author and his legal successor could feel safer. Fine to be paid to the National Museum dominated (which could be converted to captivity in case of insolvency), however, reimbursement of the loss of the injured party was also carried out by obliging the injuring party to pay "compensation", considered private law sanction. It was his innovative and significant merit that he provided procedural law regulation too. The bill was progressive because contrary to the right of inheritance practice governing at the time the surviving spouse should obtain ownership rather than right of enjoyment on the work. In section 47 of his bill he set forth that "at the same time the protection under this act shall be extended to insuring the rights of writers and artists of Transylvania until union with Transylvania is accomplished". In other words, foreseeing the union formulated (set) as a political aim he strove to extend copyright protection to eastern territories. He urged that all acts, customs and privileges contrary to the act in the making should be repealed, and he set the aim of regulating copyright in an act instead of unwritten law.

The ruler, however, threw back the bill giving the reasons that "the principles set in the bill ... should be modified for greater clarity and to fill certain gaps. ", 17 Yet, the national assembly dissolved in the meantime did not have the opportunity to analyse the returned bill again. The ruler's real reason could be searched for in the fact that, given the intention to enact the Austrian copyright law vigorously being made, he did not want to break up the unity attained. The Austrian patent was published in 1846 and at the same time the king redebated Szemere's bill in order to create harmony with the patent. The next step was the

${ }^{17}$ Knorr A.: A szerzői jog magyarázata [Explanation of copyright law]. Budapest, 1890. XIII. 
Hungarian Royal Book Reviewer Office, which submitted its report to the king on 27 July 1847. Paying regard to all that Pál Jászay made his bill, which, however, was not debated due to accelerating political events, so the above mentioned decrees continued to be in force in our country.

During the revolution two significant statutes were made that highly affected the subject area, however, none of them was a direct copyright act. First, Act XVIII of 1848 should be mentioned, which covered the freedom of the press and as part of that abolished censorship. It stipulated that setting up a printing house was conditional upon compliance with Act XVI of 1840 on traders and depositing the mandatory four thousand forint security. Bookseller activity could be performed without any permits. Act XXX of 1848 provided for setting up theatres and ensured that theatre plays could be performed freely. The above mentioned 1846 patent, entitled "Act to protect literary and artistic property against unauthorised publication, reprint and remaking" was entered into force by the open order of 29 November 1852 in our country effective as from 1 May 1853.

These statutory provisions were in force in our country until 1861 (in Transylvania until 1884) when the National Judge's Conference implemented the program of gathering valid rules of civil law (that is how the collection of Temporary Judicial Rules was made), which served as source for all proceedings until governing statutory provisions were developed. According to these rules, intellectual works enjoyed the same legal protection as any other property, now not only books were protected but "creatures of the mind" too, that is, literary, artistic and musical works as well as translations. All this included the right of public performance and reproduction. At the same time, they declared that copyright was rooted in civil law and that the content of copyright would not extend beyond the author's death; at the same time, printing of books and reprint was no longer made subject to authority's licence. ${ }^{18}$ Real practice, however, did not develop because these provisions were rather uncertain.

The year 1867 saw two new significant events in our country. First of all, owing to the international agreement entered into between Austria and France it was included in our act that performance of translation was attached to author's reservation of rights, and with respect to articles and communications published in periodicals both in regard to translation and reprint author's reservation of rights was a condition. Effective rules now included right of public performance, which was already regulated by the 1846 patent but-as it was referred to above-it was in force from 1853 to 1861 . It must have been an outstandingly

${ }^{18}$ Kelemen M.: Adatok az írói tulajdonjog hazai történelméhez [Data to the Hungarian history of writer's property right]. Budapesti Szemle, 14. 1869. 305-317., 315. 
important tool of legal protection that as a new condition published and reproduced works were registered.

In the same year the Kisfaludy Society made its second bill, which was not debated even in 1869. It actually failed because the Hungarian criminal law concept was not completed yet, so there was nothing to compare the issue of penalties and procedure to. And the part on artists reworked by the Hungarian Society of the Fine Arts did not get any further than the desk of the Minister of Justice.

The Society of Hungarian Writers and Artists headed by Gyula Kováts, making use of the 1870 German imperial statute, made a new draft in 1874, which was submitted to the parliament as a bill-however, even if it paid regard to Hungarian needs, especially due to making the commercial code, it was not approved.

The Kisfaludy Society made a third attempt in 1876, this time in cooperation with the Hungarian Academy of Sciences: it entrusted László Arany to work out the draft. The draft was first submitted to the Academy, then it was forwarded to the Minister of Justice, who convened a vocational conference to study it. The bill was submitted to the House of Representatives on 20 November 1882, which referred it to its judicial committee. The committee's report was made by 9 February 1883 already, yet the final text was attested by the House of Representatives only a year later, on 12 March 1884, and was approved by the Upper House in unchanged from. Finally, the ruler promulgated Act XVI on 7 May 1884.

\section{Bertalan Szemere's role in inland regulation of copyright-the 1844 Copyright Bill}

Bertalan Szemere noticed the necessity of protection of property in copyright law. Owing to the technological revolution, works of authors and artists became unprotected, so it was reasonable to make a duly worked out act.

Szemere's modern approach to ownership superseded the approach prevailing in the age both on international and national level, which made legal regulation simpler in several respects. The legal scientist combined the jurist's thoughts on theory and practice in his works, which is expressed the best in one of his most significant works, his report and bill on providing literary and artistic rights drafted in $1844 .{ }^{19}$

${ }^{19}$ Boytha Gy.: Szemere Bertalan és a „jövö zenéje” [Bertalan Szemere and "music of the future”]. In: Emlékkönyv Nizsalovszky Endre születésének 100. Évfordulójára [Essays in honour of Endre Nizsalovszky to commemorate the $100^{\text {th }}$ anniversary of his birth]. Budapest, 1994. 4258., 48; Senkei-Kis Z.: A szerzöi jog kialakulása és fejlödése [Evolution and development of copyright]. Első Század, 2007/1. 322-331., 328. 
He presented his bill on 23 September 1844, it was adopted with a few modifications. The bill was approved by the session of the members of the Upper House on 9 November 1844, however, the ruler did not sanction it as the court was already working on a copyright patent governing the whole empire, which entered into force also with respect to Hungary by the imperial decree dated 29 November $1852 .{ }^{20}$ In determining the core of copyright Szemere surmounted the concept of ownership prevailing both home and abroad, which simplified legal regulation in several respects. ${ }^{21}$

It was the 1865 Bavarian act that used the term copyright (Urheberrecht) for the first time on German territories; five years later it was followed by the German federal copyright act. On French territories for the first time in 1886 the Belgian legislation used the phrase "droit d' auteur" instead of the term propriété. In Hungary Act XVI of 1884 reflected Szemere's approach already, with Gyula Kováts's significant contribution, who successfully proposed the concept of "copyright" as a general technical term. ${ }^{22}$

Szemere interpreted the author's rights on his works as the author's moral rights, which is clearly reflected by his sections proposed for asserting and exercising rights. According to his approach, rights regarding the work were regulated by law in a form inseparable from the author and the author could transfer uniform copyright only with respect to its exercise. This clearly shows how much his approach to copyright was ahead of his age for in Austria it was the 1895 Act that started to follow this interpretation. ${ }^{23}$

Protection of the author's right enjoys priority since the author retains his right even if he has transferred exercise of such right to the authorised publisher and he can assert it by lawsuit if the empowered publisher fails to do so. ${ }^{24}$

By harmonising the action of the author as original copyright owner and the exclusively authorised user of the work before court against a third party and by laying the legal grounds of author's contracts, he formulated thoughts again ahead of his age. An example for the latter is section 44 in Chapter VII entitled "General provisions", which states that "as the number of editions is not determined in the contract, [...] only one edition shall be considered before the law. And as the number of copies is not determined, each edition is calculated to contain 1000 copies. ${ }^{, 25}$ It is important that the author does not transfer his own right, instead gives licence to publish, that is, such rights possessor may

\footnotetext{
${ }^{20}$ Boytha 1994. 53.

${ }^{21}$ Boytha 1994. 53.

${ }^{22}$ Boytha 1994. 55.

${ }^{23}$ Boytha 1994. 55. f.

${ }^{24}$ Boytha 1994. 56.

${ }^{25}$ Boytha 1994. 56.
} 
exercise the author's right only with respect to publishing and therefore it seems to be authorisation rather than transfer of property rights. ${ }^{26}$

Besides author's rights, Szemere separately discussed theatre plays, musical works as well as drawing and painting works, and regulated them in summary in an act. Following foreign example, he called editions without licence, referred to as pirated edition, fake edition, and would have imposed punitive sanctions. In the comparative analysis he finds that a fine is used for fake editions abroad too, which is converted to captivity in case of failure to make payment. ${ }^{27}$

Szemere's reasons also emphasises the importance of protection of author's rights stating that in Western Europe, more specifically France, being an author is a rank just as being a nobleman, a priest, a merchant. Szemere set legal regulation and social prestige of French literary life as an example to Hungarian legislation. He stressed that "civilised nations" already had laws to regulate copyright at the level of an act.

\section{1. Copyright property in Szemere's bill}

The question to be decided was whether "the group of writer's, artistic rights is a property just as any other property?" According to traditional approach maintained until then, legal relation of ownership has an absolute structure, the owner is entitled to means of legal protection against everybody. It is an important feature of the content of the right of ownership that its term is endless in theory, its subject can be alienated by the owner, and after his death it will devolve in accordance with rules of inheritance. Difficulty in the analysis of the content of author's rights is that its term is by no means endless; this righteously raises the importance of the dogmatic analysis of author's property rights. Some claim that it is a kind of sui generis property right, which "has all the attributes of property, except for infinity of hereditariness". ${ }^{28}$

For a long time they maintained the approach that writer's and artistic property is basically identical with property in the general sense. So, in its first section the 1846 Austrian act stated that products of literature and works of art constitute property of their author. Writer's and artistic property (literarisches und artistisches Eigentum) was accepted for a long time in our country too. In Hungary, only in the bourgeois age did the judicial committee of the House of Representatives state the definition "intellectual property" replacing it by the term "copyright". ${ }^{29}$

${ }^{26}$ Boytha 1994. 56.

${ }^{27}$ Boytha 1994. 56. f.

${ }^{28}$ Balogh 1991. 156.

${ }^{29}$ Balogh E.: A Szemere-féle szerzöi jogi törvényjavaslat [Szemere's Copyright Bill]. In: Ruszoly J. (szerk.): Szemere Bertalan és kora, I. [Bertalan Szemere and his age, I] Miskolc, 1991. 149-172., 157. 
One of the most important issues of the subject area was the term of protection, which was determined as fifty years from the death of the author by Bertalan Szemere. It is clear that compared to the rest of countries of Europe this is a relatively long period. The draft of the Kisfaludy Society wanted to fix sixty years as the maximum of the term of protection, however, Szemere did not consider it expedient to set a period longer than fifty years, and deemed any period shorter than that definitely disadvantageous. His reasons can be summed in three points. Quite easily, given a short term, aliens outside the author's lawful descendants enjoy the benefits arising from a work appreciated by posterity only. It is well-known, he says, that it is just the most precious works that need the greatest "investment" in time and energy, what is more, such masterpieces are produced quite often at the end of their writer's life only. So, if the term of legal protection is short, this will urge authors to write works that can be written quickly rather than works developed over a long period of time. Obviously, there is a weightier interest to support the former works. Also, it is a living possibility that the work of an author is not published during his lifetime or it is not appreciated properly, however, subsequently it is appreciated. Szemere considered it important that writers and artists should be reassured that for a term of fifty years only their family, descendants could enjoy the fruits of their ancestor's work. ${ }^{30}$

In succession of author's rights, general rules of law of inheritance/succession and contract law prevail; so, the writer can transfer the rights he is entitled to (that is, publishing) under either free or onerous transactions. During the fifty-year term the legal successor can also exercise rights, however, only with respect to publishing, that is, he is not entitled to the right of change. Szemere's bill raises the issue of the right of surviving spouse upon the author's death. If the writer has not made a last will and testament, then author's rights will devolve to the lawful inheritors. ${ }^{31}$

The surviving spouse was entitled to rights provided under widow's right (ius viduale), of which inheritance in real assets was considered exceptional, and was basically restricted to certain movables. According to the main rule, the surviving spouse was given usufruct on the goods only. A special version of legal succession is also discussed where term of protection was provided for those who-not being a relative or testamentary inheritor-got into the possession of the manuscript after the author's death and published it.

And if the manuscript is found after fifty years from the author's death only, the lawful possessor will be entitled to the right to publish for thirty years from the first edition of the work. So, Szemere set fifty years as the maximum

\footnotetext{
${ }^{30}$ Balogh 1991. 157. f.

${ }^{31}$ Balogh 1991. 158. f.
} 
term of legal protection. He promised much shorter, thirty years protection to authors who made Hungarian literary remains of the language, historical sources, charters and collections of folk legends, tales, sagas, songs and proverbs public domain. ${ }^{32}$

When the work was first published, a reservation of rights statement had to be made with regard to translation into foreign languages; this is one of the significant elements of copyright. If such statement was not made, then the right of translation became public domain; just as when the author did not publish his work in some language "living in the country" in three years from publication. So, the right of translation into German, Romanian, Slovakian etc. was available to the author for three years only; if he did not exercise it during this period, he definitely lost the opportunity to exercise it.

In publishing periodicals and volumes of studies, the publisher was entitled to writer's rights, however, a contract to the contrary could be entered into with the publisher; furthermore, the author could have his articles published in an independent collection after two years from publication. In this case it was the author's rights that were primarily protected. Rights related to works produced as a result of co-operation of several authors were provided for the authors' groups; calculation of the deadline started from the last volume for dictionaries and from publication of each volume for collections and yearbooks; according to the comments the term of protection was thirty years too. ${ }^{33}$

Double fee was not unusual since authors were entitled to general writer's rights in addition to stage rights. ${ }^{34}$ This might be in the background of the regulation of musical works too. ${ }^{35}$ Composers and their legal successors were given all the rights to publish and use their works that were granted to writers, and compositions that were performed in theatres and in concerts enjoyed rights on theatre plays too. ${ }^{36}$

"Drawing and painting works" were also regulated in the act. However, it was difficult to determine their concept; Szemere listed the most frequent versions as examples; "all works that can be produced permanently by lines and colours" enjoyed legal protection. Artists of the fine arts (and their legal successors) had rights set out in the first chapter. Assignment of the right to reproduce, as a matter of fact, did not mean that the original work was no longer owned by the artist, he could waive that solely by express statement. ${ }^{37}$

\footnotetext{
${ }^{32}$ Balogh 1991. 159.

${ }^{33}$ Balogh 1991. 159.

${ }^{34}$ Balogh 1991. 160.

${ }^{35}$ Balogh 1991. 160.

${ }^{36}$ Balogh 1991. 160.

${ }^{37}$ Balogh 1991. 160.
} 


\section{2. The concept and sanctioning of violation of writer's rights in Szemere's approach}

Szemere discussed violation of rights related to author's rights and their legal remedy in details. He carried out in-depth analysis regarding fake editions too. As a matter of fact, not only the publisher but also the author might have commited violation of rights, for that matter, against the publisher if he had his work published by another publisher too before expiry of the period set out in the contract they had entered into on that work. On the other hand, the publisher acted contrary to law if he printed and published more copies than set out in the contract. This latter version most probably occurred only when printed works produced in extra numbers were not sold or were bought by buyers but the publisher did not share the profit from sale over the stipulated number of copies with the author. Furthermore, it was considered fake edition when works printed abroad were marketed inland if the author was a resident in the country. ${ }^{38}$

Without the copyright owner's being aware and having given his consent thereto it was forbidden to make and publish any kind of extract, abridged edition or revision/adaptation that basically contained the content of the original. This bill, furthermore, considered it fake edition when introductions, explanations, notes were written to a work already in public ownership without the author's or his legal successors' permit. If it was possible, the author's (legal successor's) consent had to be obtained. Addresses, lectures held by teachers on pulpits could be published with the lecturer's permit only. Szemere cared for writings published in periodicals and newspapers; any writing concerning them could be published solely with the source specified. His bill claimed that it was fake edition when an author, in order to deceive his readers, gave a title to his work that belonged to another work already in circulation. ${ }^{39} \mathrm{He}$ dwelt on quasi fake editions too. These conducts were similar to those described above; yet, they were not considered fake editions. Accordingly, anybody was allowed to publish rules of law: no pecuniary loss was suffered thereby by anybody, on the contrary, it was in everybody's interest to make rules of law extensively known. With similar freedom it was possible to publish speeches delivered at public sessions of the parliament, municipalities and any association, with the essential restriction that the collected edition of the speeches of one person enjoyed legal protection. Also, it was possible to quote from anything freely but only word for word. Also, it was possible to adopt papers, essays, poems and oral works with full liberty in works serving educational purposes. ${ }^{40}$

\footnotetext{
${ }^{38}$ Balogh 1991. 161.

${ }^{39}$ Balogh 1991. 161.

${ }^{40}$ Balogh 1991. 162.
} 
Sanction took the form of compensation of pecuniary loss. The party causing damage was obliged to pay fine up to six hundred forints to the National Museum, however, as appropriate he had to compensate for the total damage the injured party had suffered. Instigators and abettors were responsible for their acts in proportion to liability. Parties privy to the act had joint and several liability. At that time the six hundred forint fine seemed to be moderate since in France, for example, penalty was two thousand (for habitual offenders four thousand) Francs and up to one-year imprisonment, while in England one hundred pounds and double the amount of the price of all the printed copies had to be reimbursed. ${ }^{41}$

When it was possible to determine the number of sold copies of the fake edition, the price of the original copy had to be paid to the lawful possessor for each copy, and when it was not possible to determine the number of printed or sold copies, or misdemeanour was committed to the injury of a work not even published yet, on the first occasion at least half of the number of original copies, on the second occasion the "usual price" of similar works served as measure for assessing the damage in court. The author had the right to decide whether he took over or destructed the fake copies confiscated and the metal and stone slabs and wood boards etc. necessary for producing them. In the former case the amount up to the rate of his enrichment was deducted from the amount of compensation. In the case of authors of theatre plays and musical works, whenever the play, musical piece in question was performed unlawfully, the total proceeds were every time confiscated (without deductions!), irrespective whether the work was performed individually or together with other pieces. If it was not possible to determine the proceeds subsequently, the closest proceeds at the time governed in determining the amount of compensation.

Habitual offence was severely sanctioned; basic penalty was maximum six hundred forints, and could be up to the double of the aggregate amount of compensation. The perpetrator, if he was unable to pay, could discharge penalty in the form of imprisonment. One day captivity was equal to five forints. However, it was not at the offender's discretion; penalty could be commuted to imprisonment only in the event that a) the offender had not reached legal age (men younger than twenty-four) and not having any property his parents did not intend to discharge, b) attachment on the property of the condemned had been promulgated due to bankruptcy or dissipation of funds, c) if the fine had not been produced from the obligor's property. ${ }^{42}$

\footnotetext{
${ }^{41}$ Balogh 1991. 162.

${ }^{42}$ Balogh 1991. 163.
} 


\section{3. Procedural rules of copyright disputes in Szemere's bill}

In chapter six Szemere writes in details on procedural rules of disputes. Szemere anticipated that Hungarian judicature would face a quite new phenomenon of substantive law, whose procedural rules could not be integrated without difficulties into the pattern of any of the former action types. ${ }^{43}$ That is the reason for the detailed an extended regulation, which skilfully avoids dangers of casuistry. "Punitive claim" could be submitted by the injured party only. The name 'claim' is misleading because the issue here is not that violation of author's rights was considered criminal law delictum; even the special part of the penal code bill debated in the 1843/44 national assembly did not contain such state of facts, so the attribute "punitive" should be interpreted quite generally. Here, the injured party means not only the author or his legal successor but the publisher too. So, it was primarily the publisher that was entitled to the right to bring action against violation of rights in connection with a work published, except when the author's rights were impaired by the publisher printing and publishing a number of copies higher than agreed upon in the contract entered into with the author. If, however, the publisher failed to do so during thirty days from the written notice made by the author or his legal successor, the right to submit the statement of claim would devolve to the author (legal successor). If the act violated rights related to unpublished manuscripts, the action could be instituted solely by the author. ${ }^{44}$

During the proceedings the parties could make an arrangement as well, however, such arrangement could cover compensation only and not the fine to be awarded for the benefit of the state (more specifically the National Museum). So, impairment of the author's rights must have injured both private interest and public interest. ${ }^{45}$

Furthermore, the bill orders that one bound copy of the published work "shall be placed and registered" in the proper office of the "Hungarian academy", and the author should get a receipt thereon, whose attested copy should be attached to the statement of claim. For theatre plays and musical works in manuscript, it was sufficient to register the title and the name of the author or the rights possessor and the date and place of the first performance. The copyright owner could exercise his right to institute action during two years from committing the injury. ${ }^{46}$ Term of preclusion was two years from occurrence of the objective fact of the injury. The action could be brought without paying regard to feudal legal status. The action could be brought before the authority of

\footnotetext{
${ }^{43}$ Balogh 1991. 163.

${ }^{44}$ Balogh 1991. 163.

${ }^{45}$ Balogh 1991. 163. f.

${ }^{46}$ Balogh 1991. 164.
} 
the place of injury, i.e., before the deputy sheriff in the county and before the captain in privileged districts and free royal cities. Summons were issued within eight days from receipt of the statement of claim, appearance could not be shorter than fifteen days and longer than forty-five days depending on the distance of the domicile of the sued party. ${ }^{47}$

The lawsuit was conducted in writing and both parties could make two oral pleadings, the plaintiff's statement of claim was considered one of them. The defendant had maximum five days for giving response, which could be extended on one occasion based on justified application but could not be longer than fifteen days. After the oral pleadings the parties' acts in the action were completed, which was followed by adopting the court decision and passing judgment. ${ }^{48}$

Within twenty-four hours following completion of the demonstration the court had to address all the documents of the case to the seat of experts. By then, involvement of experts had been a generally accepted practice in the western world. The Saxon code (1844) did not, the Prussian code (1837) did oblige the judge to accept the expert's opinion. ${ }^{49}$ Mostly, the court requested the seat of experts to issue their opinion at its discretion, and deemed it mandatory to request it if it believed that its own expertise was not sufficient to decide the legal dispute on the merits in a just manner. On the contrary, Szemere prescribed that it was mandatory for the court to address the documents to the seat of experts. It was not surprising that the court was not allowed to deviate from the statement issued by the experts on the injury, the court's power was restricted to assessment of the extent of legal sanction. The seat of experts was obliged to make a statement on the subject of injury every time, however, only upon the court's call on the amount of indemnity. The experts had fifteen days from receipt to adopt the expert's decision. ${ }^{50}$

The court, in possession of the written pleadings and expert's opinion, passed its judgment (the bill did not set the period available to the court), which could be contested by appeal within three days from delivery. The bill specified the Royal Court of Appeal as the court of the second instance, and no further legal remedy lay. Consequently, the bill radically simplified the feudal judicial process by declaring the judgment of the court of the second instance final and unappealable in advance. ${ }^{51}$ He proposed that the eleven members of the seat of experts were to be elected by the general meeting of the Hungarian Academy of

\footnotetext{
${ }^{47}$ Balogh 1991. 164.

${ }^{48}$ Balogh 1991. 164.

${ }^{49}$ Balogh 1991. 164.

${ }^{50}$ Balogh 1991. 164. f.

${ }^{51}$ Balogh 1991. 165.
} 
Sciences annually. They had to consist of four members of the Academy, three writers and artists outside the Academy, two librarians and two sellers of pictures and musical pieces. ${ }^{52}$ The body of experts was to take an oath before the general meeting of the Academy, and the body itself was to elect its chairman for a year. It was to adopt its resolutions by simple majority of the votes cast but at least presence of five members was necessary to constitute quorum, and two of them had to be experts, and if the issue concerned music or the arts, they had to be sellers of pictures or music. ${ }^{53}$

\section{Conclusions}

The first form of independent copyright evolved on the analogy of right of ownership at the end of the $18^{\text {th }} \mathrm{c}$.; this state in Europe lasted for almost one hundred years. Analogies drawn from right of ownership were certainly suitable for providing protection for authors' works in corporeal form for the author's benefit. Within the frameworks of the right of ownership approach, however, copyright could not be protected against distortions at all or only insufficiently by violently bending application of law. During the $19^{\text {th }} \mathrm{c}$. in Europe, copyright and patent law codification in the modern sense evolved, consistently enforcing the civil law approach and development of exclusive rights related to intellectual works. Hungarian regulation of the field of law of intellectual works, basic codices go back to the 19th century. Given the peculiarities of historical development, modern codification efforts evolved with a delay in the Age of Reforms; with respect to copyright the Bills related to Bertalan Szemere are worth mentioning. After suppression of the 1848-49 War of Independence and the 1867 Compromise, basically Austrian laws were applied. Around the middle of the 19th c., however, literary, scientific and political life in our country flourished, strongly helped by reproduction, by which Hungarian thoughts could be delivered to more and more people desiring changes. Simultaneously with progress, complaints were received on abuses of author's rights. Increasing needs of life and enhancing circulation of intellectual goods as well as politics aimed at liberating the press brought along more independent development of author's rights. In Hungary, in the beginning, as a result of state law relation, the development of author's rights was similar to the process in Austria, and then, upon termination of this connection, it went through independent progress.

\footnotetext{
${ }^{52}$ Balogh 1991. 165.

${ }^{53}$ Balogh 1991. 165.
} 
Др Тамаш Нойари, ванредни иррофесор

Универзииеетиа Карољ Гашӣар у Будимӣешими

\section{Заштита интелектуалне својине у мађарском праву у XIX веку}

Сажеетиак: Збоі̄ йосебних истиоријских йрилика, радови на стиварању модерне кодификаиије ірађанскоі йрава у Уїарској зайочиғу са извесним зака-

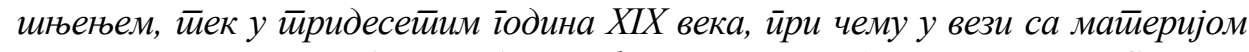
ауйорскоі йрава йосебно ииреба исйаћи законски ирредлоі Берииалана Семереа (Szemere Bertalan). По сузбијаюу борбе за независности (1849) и Аустироуїарске Наїодбе (1867), у Уїарској ирримењивали су се ауситријски закони. Истиори-

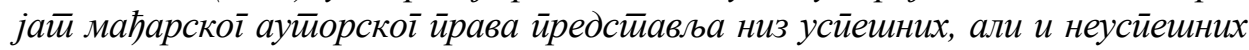
иокушаја да се изврши кодификаиија ове іране иррава, ири чему ииреба исииаћи да се неусвајање йојединих законских ӣредлоїа може йре йрийисайи истиоријским околностиима, неіо садржини ирредложених закона. Законски иредлой Берйалана Семереа од 1844. іодине није био усвојен збоі одбијања монарха да їа ирроїласи. После ере иарских йаиеенайа и уредаба, као и закључења На-

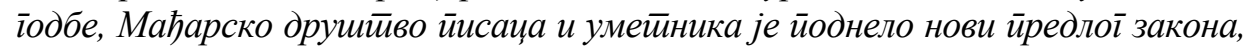
чије усвајање је йакође изостиало. Међуииим, Тріовачки законик, усвојен законским акииом бр. ХХХVII од 1875. іодине, имао је йосебно йойлавље йосвећено йравној реі̄улатииви издавачкоі уїовора. Први закон о ауйорском йраву, закон бр. XVI од 1884. іодине, усвојен је на инииијаииву Ласла Арања (Arany

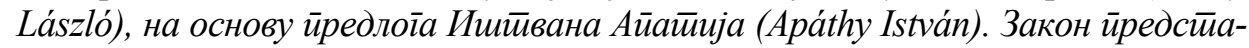
вља модерну кодификаиију, ирилаїођену условима ірађанскоі друшиива, који је йој мери усвојио најзначајније йековине йадашње ирравне науке у обласиии иниеелекииуалне својине, као ниједан друіи закон од йада. У овом раду се даје ириказ иредлоїа Ферениа Толдија (Toldy Ferenc) о мерама зашимиие йрава иниелекииуалне својине, као и ирвих облика иравне зашииие ауйорских дела у Уїарској. Најзад, биће извршена анализа улоіе Берииалана Семереа у насйоја-

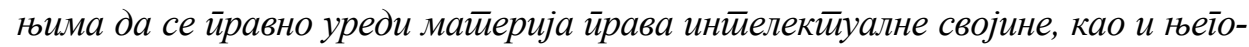
вої ирредлоїа Закона о ауйорском ӣраву од 1844. іолине.

Кључне речи: ирраво инйелекииуалне својине, мађарски Закон о ауйорском йраву, Ферени Толди, Берииалан Семере 